\author{
Paweł Florek ${ }^{\mathrm{a})^{*}}$, Tomasz Kołodziejczyk ${ }^{\mathrm{a})}$ \\ a) Scientific and Research Centre for Fire Protection - National Research Institute / Centrum Naukowo-Badawcze Ochrony \\ Przeciwpożarowej im. Józefa Tuliszkowskiego - Państwowy Instytut Badawczy \\ *Corresponding author / Autor korespondencyjny: pflorek@cnbop.pl
}

\title{
Supporting Evacuation of Disabled People - Organizational and Technological Challenges
}

\section{Wsparcie ewakuacji osób niepetnosprawnych - wyzwania organizacyjne i technologiczne}

\begin{abstract}
Aim: The aim of this publication is to present the most important aspects concerning the conditions for evacuation of people with various types of disabilities - from mobility problems, to reduced perception in the event of a threat, and to indicate the most important challenges both in terms of legal regulations, as well as organizational and technological conditions for ensuring effective evacuation of disabled people.

Introduction: People with disabilities are a group that requires special consideration when planning evacuation from public utility facilities, because many of these people - depending on the type and degree of their dysfunction - will not be able to evacuate from the danger zone on their own. The inspection carried out in 2019 by the Delegation of the Supreme Audit Office in Poznań confirmed the need to adapt the applicable legal regulations in this regard (in practice, fire safety instructions, evacuation plans, staff training and equipping facilities with adequate equipment supporting the evacuation of people with disabilities) [1]. In addition to legal and technological aspects, a very important factor in the effective evacuation of disabled people are organizational solutions adopted in a given facility, which should take into account the individual specificity (cubature) and functions of a given facility. Methodology: As part of the research process, theoretical research was used, such as: analysis of literature and legal documents, synthesis, generalization, inference, comparison and analogy. During the research, national and foreign sources (from the United States and Great Britain) were analyzed. The selection of individual countries was guided by the level of development of the solutions adopted in these countries dedicated to supporting the evacuation of disabled people in a situation of threat to their life or health, as well as the availability of data sources.

Conclusions: The presented analysis of the conditions for the evacuation of people with disabilities from public utility buildings shows the challenges that both the legislator and managers of facilities in the country face in this area, as well as the emergency services. The latter - similarly to people with disabilities - are the systemic beneficiaries of the desired changes in the area of law and tactics of rescue operations, from the moment of alerting about an event in the facility where there are people who are unable to evacuate themselves. Introducing good practices, verified in other countries, into common application, should significantly improve rescue operations. The expected effect will be to shorten the time of providing help to all people unable to evacuate themselves in an emergency - regardless of their number, as well as the type and specificity of the public facility in which the life or health threatening situation occurred.

Keywords: evacuation of disabled people, public utility buildings, intelligent construction, modelling and computer simulations, individual evacuation plan Type of article: review article
\end{abstract}

Received: 29.06.2021; Reviewed: 09.07.2021; Accepted: 12.07.2021;

Authors' ORCID IDs: Paweł Florek - 0000-0002-9690-3989; Tomasz Kołodziejczyk - 0000-0002-1234-2548

The authors contributed the equally to this article;

Please cite as: SFT Vol. 57 Issue 1, 2021, pp. 134-144, https://doi.org/10.12845/sft.57.1.2021.9;

This is an open access article under the CC BY-SA 4.0 license (https://creativecommons.org/licenses/by-sa/4.0/).

\section{ABSTRAKT}

Cel: Celem niniejszej publikacji jest przedstawienie najważniejszych aspektów dotyczących warunków ewakuacji osób z różnymi rodzajami niepełnosprawności - począwszy od problemów z poruszaniem się, na ograniczeniu percepcji w sytuacji wystąpienia zagrożenia skończywszy - oraz wskazanie najważniejszych wyzwań zarówno na płaszczyźnie regulacji prawnych, jak i warunków organizacyjnych oraz technologicznych dla zapewnienia skutecznej ewakuacji osób niepełnosprawnych.

Wprowadzenie: Osoby niepełnosprawne to grupa wymagająca szczególnego uwzględnienia w przypadku planowania ewakuacji z obiektów użyteczności publicznej, ponieważ wiele z tych osób - w zależności od rodzaju i stopnia posiadanej dysfunkcji - nie będzie w stanie samodzielnie ewakuować się 
ze strefy zagrożenia. Przeprowadzona w 2019 roku kontrola Delegatury Najwyższej Izby Kontroli w Poznaniu potwierdziła konieczność dostosowania obowiązujących regulacji prawnych w tym zakresie (w praktyce instrukcji bezpieczeństwa pożarowego, planów ewakuacji, przeszkolenia personelu oraz wyposażenia obiektów w adekwatny sprzęt wspomagający ewakuację osób z niepełnosprawnością) [1]. Poza aspektami prawnymi i technologicznymi, bardzo istotny czynnik skutecznej ewakuacji osób niepełnosprawnych stanowią przyjęte w danym obiekcie rozwiązania organizacyjne, które powinny uwzględniać indywidualną specyfikę (kubatura) oraz funkcje danego obiektu.

Metodologia: W ramach procesu badawczego wykorzystano badania teoretyczne, takie jak: analiza literatury i dokumentów prawnych, synteza, uogólnianie, wnioskowanie, porównanie oraz analogia. Podczas badań dokonano analizy źródeł krajowych oraz zagranicznych (ze Stanów Zjednoczonych Ameryki i Wielkiej Brytanii). Przy doborze poszczególnych państw kierowano się poziomem rozwoju przyjętych w tych państwach rozwiązań dedykowanych wsparciu ewakuacji osób niepełnosprawnych w sytuacji zagrożenia dla ich życia lub zdrowia, a także dostępnością źródeł danych.

Wnioski: Zaprezentowana analiza warunków ewakuacji osób z niepełnosprawnością z obiektów użyteczności publicznej pokazuje wyzwania, jakie w tym obszarze stoją zarówno przed legislatorem, jak i zarządcami obiektów w kraju, a także przed służbami ratowniczymi. Te ostatnie - podobnie jak osoby niepełnosprawne - są systemowym beneficjentem pożądanych zmian w obszarze przepisów prawa oraz taktyki prowadzonych działań ratowniczych, już od momentu alarmowania o zdarzeniu w obiekcie, w którym przebywają osoby niezdolne do samodzielnej ewakuacji. Wprowadzenie do powszechnego zastosowania dobrych praktyk, sprawdzonych w innych państwach, powinno w wyraźny sposób usprawnić działania ratownicze. Spodziewanym efektem będzie skrócenie czasu dotarcia z pomocą do wszystkich osób niezdolnych do samodzielnej ewakuacji w sytuacji zagrożenia - bez względu zarówno na ich liczbę, jak i na rodzaj i specyfikę obiektu użyteczności publicznej, w którym doszło do sytuacji zagrażającej życiu lub zdrowiu.

Słowa kluczowe: ewakuacja osób niepełnosprawnych, obiekty użyteczności publicznej, inteligentne budownictwo, modelownie i symulacje komputerowe, indywidualny plan ewakuacji

Typ artykułu: artykuł przeglądowy

Przyjęty: 29.06.2021; Zrecenzowany: 09.07.2021; Zaakceptowany: 12.07.2021;

Identyfikatory ORCID autorów: Paweł Florek - 0000-0002-9690-3989; Tomasz Kołodziejczyk - 0000-0002-1234-2548;

Autorzy wnieśli równy wkład merytoryczny w powstanie artykułu;

Proszę cytować: SFT Vol. 57 Issue 1, 2021, pp. 134-144, https://doi.org/10.12845/sft.57.1.2021.9;

Artykuł udostępniany na licencji CC BY-SA 4.0 (https://creativecommons.org/licenses/by-sa/4.0/).

\section{Introduction}

Currently, the regulations in Poland do not precisely regulate how to evacuate disabled people. This is confirmed by the results of the inspection carried out by the Delegation of the Supreme Audit Office in Poznań in 2019 [1]. They point to five critical areas related to the safe evacuation of people with disabilities. These are:

- no practical verification of the conditions and organization of evacuation of people with disabilities $(50 \%$ of facilities),

- no employee training in the area of evacuation of people with disabilities (37.5\%),

- no specialized equipment for the evacuation of people with disabilities (100\%),

- no knowledge about the efficiency of the users of the facility (37.5\%),

- no evacuation procedures for people with disabilities (62.5\%).

When analysing the specific needs of people with disabilities, it is necessary to indicate the need to use dedicated for individual groups of people in the evacuation scheme. The obligation to guarantee the safety of building users and to enable the evacuation of disabled people - in accordance with applicable law in Poland - rests with the managers of public buildings. This is regulated by relevant laws and regulations referred to in the following sections of the article. In the public perception, a peculiar novelty among the provisions of the law may be the Act of 19 July 2019 on providing accessibility

\section{Wprowadzenie}

Obecnie w Polsce przepisy nie regulują precyzyjnie, w jaki sposób należy przeprowadzić ewakuację osób niepełnosprawnych. Potwierdzają to wyniki kontroli przeprowadzonej przez Delegaturę Najwyższej Izby Kontroli w Poznaniu w 2019 r. [1]. Wskazują one na pięć krytycznych obszarów związanych z bezpieczną ewakuacją osób z niepełnosprawnościami. Są to:

- brak praktycznego sprawdzenia warunków i organizacji ewakuacji osób z niepełnosprawnością (50\% obiektów),

- brak szkoleń pracowników w obszarze ewakuacji osób z niepełnosprawnością (37,5\%),

- brak specjalistycznego wyposażenia do ewakuacji osób z niepełnosprawnością (100\%),

- brak wiedzy o stanie sprawności użytkowników obiektu $(37,5 \%)$,

- brak procedur ewakuacji osób z niepełnosprawnością (62,5\%).

Analizując specyficzne potrzeby osób z niepełnosprawnością, należy wskazać na potrzebę dedykowanego poszczególnym grupom osób schematu ewakuacji. Obowiązek zagwarantowania bezpieczeństwa użytkowników budynku oraz umożliwienia ewakuacji osób niepełnosprawnych - zgodnie z obowiązującymi przepisami prawa w Polsce - spoczywa na zarządcach obiektów użyteczności publicznej. Regulują to odpowiednie ustawy i rozporządzenia, które przywołano w kolejnych podrozdziałach artykułu. W odbiorze społecznym swoistą nowością wśród przepisów prawa może być ustawa z dnia 19 lipca 2019 r. o zapewnianiu dostępności osobom ze 
to people with special needs [2], which explicitly points to the need to ensure the possibility of evacuating or saving people with disabilities. The government program Accessibility Plus [3], which is relatively new in the public awareness, is also complementary to the aforementioned Act. In fact, this program is the first and comprehensive approach to accessibility in Poland. Its aim is to ensure free access to goods, services and the possibility of participation in social and public life for people with special needs and to adapt public space, architecture, transport and products to the requirements of all citizens. As part of the European funds, as well as funds from the budgets of local government units and public and private national funds, directions and specific projects with a total value of PLN 23 billion (for 2018-2025) have been planned in the Accessibility Plus program. Taking into account the complexity and wealth of this program, it is worth emphasizing that among the areas indicated as priority in terms of improving accessibility, there are conditions for the evacuation of people with special needs, including people with disabilities. The resources of the State Fund for Rehabilitation of Disabled People (PFRON) - a public administration body dedicated to supporting rehabilitation and employment of disabled people play a significant role in the implementation of the Accessibility Plus program. The analyses carried out under the Accessibility Plus program show that in Poland there may be as many as 7 million dependent people with special needs. A characteristic feature of each person in this social group will also be special protective needs, including the need for direct support in an emergency that requires evacuation. According to the estimates, such a large social group of people with special needs will systematically grow, mainly due to unfavourable demographic trends. Therefore, an essential challenge requiring planning and intervention in a systematic and long-term manner in emergency situations is adapting public space to the specific needs of this group. The possibility of adapting the best practices in this area from other developed countries in the world (such as the United States of America or the United Kingdom) may result in significant progress and acceleration of saturation of public infrastructure with solutions that will guarantee support for effective help for dependent people in emergencies that threaten their lives or health. Therefore, the issues discussed in the article constitute a very important and certainly up-to-date security context. It seems that defining the standards of conduct in the event of threats in public utility facilities for people with special protective needs in a situation requiring their evacuation is not only a necessity resulting from a systematic increase in infrastructure or unfavourable demographic trends that feed such a sensitive social group, but also a standard in a sense defining the level of civilization development of countries aspiring to be called developed. These are countries available to all citizens regardless of their dysfunctions and in the taken context - safe, or at least systematically trying, due to dedicated legal, technological and organizational solutions, to prevent threats and protect those who will not be able to take care of themselves on their own in an emergency. szczególnymi potrzebami [2], w której wskazuje się wprost na konieczność zapewnienia możliwości ewakuacji lub uratowania osób niepełnosprawnych. Komplementarnym do wspomnianej ustawy jest również relatywnie nowy w świadomości społecznej rządowy program Dostępność Plus [3]. Program ten w istocie stanowi pierwsze i kompleksowe ujęcie tematyki dostępności w Polsce. Jego celem jest zapewnienie swobodnego dostępu do dóbr, usług oraz możliwości udziału w życiu społecznym i publicznym osób o szczególnych potrzebach oraz dostosowanie przestrzeni publicznej, architektury, transportu i produktów do wymagań wszystkich obywateli. W ramach funduszy europejskich, a także środków pochodzących z budżetów jednostek samorządu terytorialnego oraz publicznych i prywatnych środków krajowych, zaplanowano w programie Dostępność Plus kierunki i konkretne przedsięwzięcia o łącznej wartości 23 miliardów złotych (na lata 2018-2025). Biorąc pod uwagę kompleksowość oraz zasobność tego programu, na podkreślenie zasługuje fakt, że wśród obszarów wskazanych jako priorytetowe, jeśli chodzi o poprawę ich dostępności, znalazły się właśnie warunki ewakuacji osób o szczególnych potrzebach, w tym osób z niepełnosprawnością. Znaczący udział w realizacji programu Dostępność Plus odgrywają zasoby Państwowego Funduszu Rehabilitacji Osób Niepełnosprawnych (PFRON) - organu administracji publicznej dedykowanego do wsparcia rehabilitacji oraz zatrudnienia osób niepełnosprawnych. Z przeprowadzonych w ramach programu Dostępność Plus analiz wynika, że w Polsce może być nawet 7 mln osób niesamodzielnych, o szczególnych potrzebach. Cechą charakterystyczną dla każdej osoby w tej grupie społecznej będą również szczególne potrzeby ochronne, w tym potrzeba bezpośredniego wsparcia w sytuacji zagrożenia, powodującej konieczność ewakuacji. Tak liczna grupa społeczna osób o szczególnych potrzebach będzie według szacunków systematycznie się powiększać, głównie z powodu niekorzystnych trendów demograficznych. Dlatego niezbędnym wyzwaniem wymagającym planowania i interwencji w sposób systematyczny i długofalowy jest dostosowanie przestrzeni publicznej do szczególnych potrzeb w tej grupie w sytuacjach zagrożenia. Możliwość adaptacji najlepszych praktyk w tym obszarze z innych państw rozwiniętych na świecie (jak chociażby Stany Zjednoczone Ameryki czy Wielka Brytania) może zaowocować znaczącym progresem i przyspieszeniem nasycenia infrastruktury publicznej rozwiązaniami, które będą gwarantować wsparcie dla skutecznej pomocy osobom niesamodzielnym w nagłych sytuacjach zagrażających ich życiu lub zdrowiu. Zagadnienia podejmowane $w$ artykule stanowią zatem bardzo istotny i z pewnością aktualny kontekst bezpieczeństwa. Wydaje się, że określenie standardów postępowania na wypadek zagrożeń w obiektach użyteczności publicznej dla osób o szczególnych potrzebach ochronnych w sytuacji wymagającej ich ewakuacji to nie tylko konieczność wynikająca z systematycznego przyrostu infrastruktury, czy też niekorzystnych trendów demograficznych, które zasilają tak newralgiczną grupę społeczną, ale też standard określający w pewnym sensie poziom rozwoju cywilizacyjnego państw aspirujących do miana rozwiniętych. Mowa tu o krajach dostępnych dla wszystkich obywateli bez względu na posiadane dysfunkcje oraz w podejmowanym kontekście - bezpiecznych, a przynajmniej starających się systemowo za sprawą 
dedykowanych rozwiązań prawnych, technologicznych i organizacyjnych zapobiegać zagrożeniom i chronić tych, którzy samodzielnie nie będą zdolni do zatroszczenia się o siebie w sytuacji zagrożenia.

\section{Good practices on the example of Great Britain and the United States of America}

An extremely interesting, good practice in Great Britain is, among others, planning for one year in advance the organization of evacuation trials, including financial compensation for posted or recruited workers to be responsible for providing emergency first aid and evacuation to people with special needs. Moreover, an individualized approach to the issue of evacuation, commonly used in Great Britain, seems worth following, taking into account both the specificity of each facility and the types of dysfunction of potential users with special needs. In practice, this approach works in the form of individual evacuation plans, which as a standard contain a list of fire-fighting devices existing in the facility, applicable procedures in the event of a fire, delineated evacuation routes dedicated to the movement of people with disabilities, as well as a list of all improvements made in the facility for people with disabilities. It is also good practice to distinguish - already at the design stage - evacuation plans for individual facilities, the specificity of each type of disability, including hearing, vision, motor dysfunction, and perception (cognitive). Individual UK Evacuation Plans are developed both for staff permanently resident in a building (employees) and for those using services offered in a given public facility. In case of employees, plans are prepared by the departments of human resources together with the interested parties, while in case of outsiders visiting the building, most often the obligation to prepare the plans rests with the facility manager. There is a widespread belief in the United Kingdom, which is confirmed in practice, that the key to an effective evacuation is constructive cooperation in the development of evacuation plans for as many parties as possible, which can add value to the creation of such an important procedure that, in an emergency, is aimed at minimizing (as much as possible) the risk of losses to people (life and health), as well as to property. The issue of prioritizing the special needs of people with disabilities is a clear standard of the British society and of the Royal Administration at all levels. This is also confirmed by the applicable regulations, according to which insufficient coordination of design activities in the field of evacuation plans by the facility manager or managers may be interpreted not only as non-compliance with fire protection requirements, but also as a manifestation of discrimination against people with special protective needs. Some of the Anglo-Saxon solutions - in particular an individual approach aimed at the fullest possible adaptation of the protective solutions adopted in the facilities - are also present in the United States. The best example of this is a guide [4] serving as guidelines for the development of evacuation schemes for people with disabilities along with evacuation schemes adequate to five specific types of disability

\section{Dobre praktyki na przykładzie Wielkiej Brytanii i Stanów Zjednoczonych Ameryki}

Niezwykle interesującą, dobrą praktyką stosowaną w Wielkiej Brytanii jest $m$.in. planowanie z rocznym wyprzedzeniem organizacji próbnych ewakuacji, uwzględniających finansową gratyfikację dla pracowników delegowanych lub zrekrutowanych w celu odpowiedzialności za udzielanie pierwszej pomocy osobom o szczególnych potrzebach w sytuacji zagrożenia i ewakuacji. Ponadto, godnym naśladowania wydaje się, stosowane powszechnie w Wielkiej Brytanii, zindywidualizowane podejście do zagadnienia ewakuacji, uwzględniające zarówno specyfikę każdego z obiektów, jak i rodzajów dysfunkcji potencjalnych użytkowników o szczególnych potrzebach. Takie podejście w praktyce funkcjonuje w postaci indywidualnych planów ewakuacji, które standardowo zawierają wykaz istniejących w obiekcie urządzeń przeciwpożarowych, obowiązujących procedur postępowania na wypadek pożaru, wytyczonych dróg ewakuacji dedykowanych osobom z niepełnosprawnością, a także wykaz wszelkich usprawnień powstałych w obiekcie z myślą o osobach niepełnosprawnych. Dobrą praktyką jest również rozróżnianie - już na etapie projektowania - planów ewakuacji dla poszczególnych obiektów, specyfiki poszczególnych rodzajów niepełnosprawności, w tym deficytów narządu słuchu, wzroku, dysfunkcji ruchowej, a także percepcji (poznawczej). Indywidualne Plany Ewakuacji w Wielkiej Brytanii opracowuje się zarówno dla personelu na stałe przebywającego w obiekcie (pracownicy), jak i dla osób korzystających z usług oferowanych w danym obiekcie użyteczności publicznej. W przypadku pracowników plany są opracowywane przez działy kadr wspólnie z zainteresowanymi, natomiast w odniesieniu do osób postronnych, odwiedzających budynek najczęściej zobowiązanie przygotowania planów spoczywa na zarządcy obiektu. W Wielkiej Brytanii panuje powszechne przeświadczenie, które potwierdza się w praktyce, że kluczem do skutecznej ewakuacji jest konstruktywna współpraca na etapie opracowania planów ewakuacji możliwie wszystkich stron, mogących wnieść wartość dodaną do stworzenia tak istotnej procedury, która w sytuacji zagrożenia ma na celu w jak największym zakresie zminimalizować ryzyko strat w ludziach (życie i zdrowie), a także w mieniu. Kwestia priorytetowego podejścia do szczególnych potrzeb osób niepełnosprawnych jest oczywistym standardem brytyjskiego społeczeństwa oraz organów administracji królewskiej na każdym poziomie. Znajduje to potwierdzenie również w obowiązujących przepisach, zgodnie z którymi niedostateczne skoordynowanie działań projektowych w zakresie planów ewakuacji przez zarządcę lub zarządców obiektu może zostać odczytane jako nie tylko niezgodność $\mathrm{z}$ wymaganiami w zakresie ochrony przeciwpożarowej, ale również jako przejaw dyskryminacji osób o szczególnych potrzebach ochronnych. Niektóre z rozwiązań anglosaskich - w szczególności indywidualne podejście mające na celu możliwie pełne dostosowanie przyjętych w obiektach rozwiązań 
(motor, sight, hearing, speech and perception dysfunctions). It is a standard used in fire protection in the United States of America, which - in addition to the indications on how to plan an evacuation adapted to the five types of dysfunctions - defines four stages of evacuation, i.e. alarming, marking evacuation routes, self-evacuation and evacuation with assistance (support of a second person). This American standard is designed to accommodate individual adaptation of an evacuation plan to the characteristics of each disabled person on site by offering a personal checklist for designers, facility managers and end users (i.e. disabled people) that can be used to optimize evacuation plans. This list contains information about a given disabled person in the form of a declaration regarding the most precisely defined target location in the facility where the disabled person intends to stay and synthetic data on the type of dysfunctions, the use of a guide dog, as well as contact and personal details. Very important information, included as obligatorily in the personal checklist, is data on whether a specific person will actually require support in an emergency and the need to evacuate, as well as any details of persons or animals assisting a disabled person (including information on the assistant's training level). Other very important information contained in the list is that concerning the solutions adopted in the facility to enable the effective evacuation of disabled people. The data relates to the adequacy of the solutions adopted in a facility to the specific needs of a disabled person, including verification of the degree of understanding of the used markings of the evacuation route, methods of alerting in the situations of a fire, flood, terrorist attack, storm and seismic shocks. The checklist in question also includes questions that ultimately verify the level of understanding of the adopted evacuation procedures as well as the availability and readability of passageways, access routes and marked escape routes. The adopted standard in the form of a dedicated guide and personal checklists enables the identification of disabled people each time.

\section{Polish conditions}

The regulation of the Minister of Infrastructure of 12 April 2002 on the technical conditions to be met by buildings and their location (i.e. Polish Journal of Laws: Dz. U. z 2015 r. poz. 1422) [5] and the regulation of the Minister of Internal Affairs and Administration of 2 December 2015 on agreeing a construction design in terms of fire protection (Polish Journal of Laws: Dz. U. z 2015 r. poz. 2117) [6] directly impose the obligation to guarantee the safety of building users and enable the evacuation of people. The new formal and legal regulation dedicated to people with disabilities ochronnych - występują również w Stanach Zjednoczonych Ameryki. Najlepszym tego przykładem jest przewodnik [4] służący jako wytyczne do opracowywania schematów ewakuacji osób z niepełnosprawnością wraz ze schematami ewakuacji adekwatnymi do pięciu określonych rodzajów niepełnosprawności (dysfunkcji ruchowej, wzroku, słuchu, mowy oraz percepcji). Jest to standard stosowany w ochronie przeciwpożarowej w Stanach Zjednoczonych Ameryki, który - poza wskazaniami, w jaki sposób planować ewakuację dostosowaną do wymienionych pięciu rodzajów dysfunkcji - określa cztery etapy ewakuacji, tj.: alarmowanie, oznaczenie dróg ewakuacyjnych, samoewakuację oraz ewakuację z asystą (wsparciem drugiej osoby). Ten amerykański standard z założenia uwzględnia możliwość indywidualnego dostosowania planu ewakuacji do cech każdej osoby niepełnosprawnej przebywającej na terenie obiektu, oferując opracowaną dla projektantów, zarządców obiektów oraz użytkowników końcowych (tj. osób niepełnosprawnych) personalną listę kontrolną, za pomocą której można zoptymalizować plany ewakuacji. Lista ta zawiera informacje na temat danej osoby niepełnosprawnej w postaci deklaracji dotyczącej możliwie jak najbardziej precyzyjnie określonej lokalizacji docelowej w obiekcie, w której osoba niepełnosprawna ma zamiar przebywać oraz syntetyczne dane o rodzaju posiadanych dysfunkcji, korzystania z asysty psa przewodnika, a także dane kontaktowe i personalne. Bardzo ważną informacją zawartą obligatoryjnie w personalnej liście kontrolnej są dane odnośnie tego, czy konkretna osoba faktycznie będzie wymagała wsparcia w sytuacji zagrożenia i konieczności ewakuacji, a także ewentualne dane szczegółowe dotyczące osób lub zwierząt asystujących osobie niepełnosprawnej ( $w$ tym informacje o poziomie wyszkolenia asystenta). Innymi spośród bardzo ważnych informacji, które zawiera lista, są te dotyczące przyjętych w obiekcie rozwiązań mających za zadanie umożliwić skuteczną ewakuację osób niepełnosprawnych. Dane te dotyczą adekwatności przyjętych w obiekcie rozwiązań do szczególnych potrzeb osoby niepełnosprawnej, w tym weryfikację stopnia zrozumienia zastosowanych oznaczeń dróg ewakuacyjnych, sposobów alarmowania w sytuacjach pożaru, powodzi, ataku terrorystycznego, nawałnicy oraz wstrząsów sejsmicznych. Lista kontrolna, o której mowa, zawiera również pytania ostatecznie weryfikujące poziom zrozumienia przyjętych procedur ewakuacji oraz dostępność i czytelność przejść, dojść i wytyczonych ścieżek ewakuacji. Przyjęty standard w postaci dedykowanego przewodnika i personalnych list kontrolnych umożliwia każdorazową identyfikację osób niepełnosprawnych.

\section{Polskie uwarunkowania}

Rozporządzenie Ministra Infrastruktury z dnia 12 kwietnia 2002 r. w sprawie warunków technicznych, jakim powinny odpowiadać budynki i ich usytuowanie (tj. Dz. U. z 2015 r. poz. 1422) [5] oraz rozporządzenie Ministra Spraw Wewnętrznych i Administracji z dnia 2 grudnia 2015 r. w sprawie uzgadniania projektu budowlanego pod względem ochrony przeciwpożarowej (Dz. U. z 2015 r. poz. 2117) [6] wprost nakładają obowiązek zagwarantowania bezpieczeństwa użytkowników budynków oraz umożliwienia ewakuacji osób. Nowym 
in emergency situations is the Act of 19 July 2019 on ensuring accessibility to people with special needs [2]. This act, in Art. 6, specifies the minimum requirements to ensure accessibility to people with special needs, including the necessity to provide evacuation. According to the regulation of the Minister of Interior and Administration of 7 June 2010 on fire protection of buildings, other structures and areas (Polish Journal of Laws: Dz. U. z 2010 r. Nr 109, poz. 719) [7] appropriate evacuation conditions should be provided to enable quick and safe exit from the danger zone, including the fire zone from anywhere in the building public utility, which is intended for the presence of people. Evacuation conditions should be adapted to the number and fitness level of people in the building and its function, structure and dimensions, because life and health of people in the danger zones depends on the efficiency of evacuation. According to the provisions of the aforementioned regulation $(\S 17(1,2))$, in addition in some facilities, at least once a year or two years, the organization and conditions of evacuation from the entire facility should be practically verified. Managing people's behaviour in a hazardous situation is possible thanks to the assumption of the most optimal scenario for the operation of devices and the principles of cooperation, which indicate to the people in the building a safe evacuation route from the hazardous area.

\section{Disability - a social issue and a challenge in rescue}

According to data from the World Health Organization (WHO), there are almost one billion people with disabilities in the world [8]. In Poland, according to the information contained in the aforementioned government program Accessibility Plus for 2018 $-2025,30 \%$ of the society may have permanent or temporary limitations in mobility or perception [1]. Depending on the adopted definition of disability, this group in Poland may have from 4.9 million to even 7.7 million people, although there are no precise statistics. It is not known exactly what percentage of that number are people with motor disabilities. It is assumed that they constitute about $10 \%$ of the total number. About 1.8 million people with visual disabilities live in Poland, including about 5,000 people who are completely blind (according to the estimates of non-governmental organizations). Currently, the regulations in Poland do not precisely regulate how to evacuate disabled people. This is confirmed by the results of the already mentioned audit of the NIK Delegation in Poznan [1].

When analysing the specific needs of disabled people, it is necessary to point out the need to create tool support and an evacuation scheme dedicated to individual groups of people. In case of people with hearing impairment and deaf people, support in the form of text messages, visual alarm system, vibration function and an application navigating inside a facility should be used. The function of locating a person in any part of a facility in real time is very important in order to shorten the arrival time of the rescuers or law enforcement services, and ultimately bystanders uregulowaniem formalno-prawnym, dedykowanym dla osób niepełnosprawnych w sytuacjach zagrożenia jest ustawa $z$ dnia 19 lipca 2019 r. o zapewnianiu dostępności osobom ze szczególnymi potrzebami [2]. Ustawa ta w art. 6 określa minimalne wymagania służące zapewnieniu dostępności osobom ze szczególnymi potrzebami, wśród nich konieczność zapewnienia możliwości ewakuacji. Zgodnie z rozporządzeniem Ministra Spraw Wewnętrznych i Administracji z dnia 7 czerwca 2010 r. w sprawie ochrony przeciwpożarowej budynków, innych obiektów budowlanych i terenów (Dz. U. z 2010 r. Nr 109, poz. 719) [7] z każdego miejsca w budynku użyteczności publicznej, które jest przeznaczone obecności ludzi, powinny być zapewnione odpowiednie warunki ewakuacji umożliwiające szybkie i bezpieczne opuszczanie strefy zagrożonej, w tym objętej pożarem. Warunki ewakuacji powinny być dostosowane do liczby i stanu sprawności osób przebywających w budynku oraz do jego funkcji, konstrukcji i wymiarów, gdyż od sprawności ewakuacji zależy życie i zdrowie osób znajdujących się w strefach zagrożenia. Według zapisów przywołanego rozporządzenia (§ 17 ust. 1,2) dodatkowo w niektórych obiektach, co najmniej raz na rok lub dwa lata, powinno się praktycznie zweryfikować organizację oraz warunki ewakuacji z całego obiektu. Zapanowanie nad zachowaniem ludzi w sytuacji zagrożenia jest możliwe dzięki założeniu najbardziej optymalnego scenariusza działania urządzeń oraz zasad współdziałania, które wskazują osobom przebywającym w budynku bezpieczną drogę ewakuacji z miejsca zagrożenia.

\section{Niepełnosprawność - kwestia społeczna i wyzwanie $w$ ratownictwie}

Według danych Światowej Organizacji Zdrowia (WHO) na świecie jest prawie miliard osób z niepełnosprawnością [8]. W Polsce, zgodnie $z$ informacjami zawartymi we wspomnianym już rządowym programie Dostępność Plus na lata 2018-2025, 30\% społeczeństwa może mieć trwałe lub czasowe ograniczenia w mobilności czy percepcji [1]. W zależności od przyjętej definicji niepełnosprawności ta grupa może liczyć w Polsce od 4,9 mln do nawet 7,7 mln osób, choć brakuje dokładnej statystyki. Nie wiadomo dokładnie, jaki procent stanowią osoby z niepełnosprawnością ruchową. Przyjmuje się, że stanowią one około $10 \%$ ogólnej liczby. W Polsce żyje około 1,8 $\mathrm{mln}$ osób z niepełnosprawnością wzroku, w tym jak szacują organizacje pozarządowe - ok. 5 tysięcy osób całkowicie niewidomych. Obecnie w Polsce przepisy nie regulują precyzyjnie, w jaki sposób należy przeprowadzić ewakuację osób niepełnosprawnych. Potwierdzają to wyniki przywoływanej już kontroli Delegatury NIK w Poznaniu [1].

Biorąc pod uwagę szczególne potrzeby osób niepełnosprawnych należy skupić się przede wszystkim na wsparciu tych osób w zakresie skutecznej ewakuacji w sytuacji zagrożenia. W przypadku osób niedosłyszących i głuchych należy zastosować wsparcie $w$ formie wiadomości tekstowych, sytemu alarmującego w postaci wizualnej, funkcji wibracji oraz aplikacji nawigującej wewnątrz obiektu. Bardzo istotną jest funkcja umożliwiająca lokalizowanie osoby w dowolnej części obiektu w czasie rzeczywistym, w celu skrócenia czasu dotarcia ratowników lub służb 
who are able to provide support (assistance) during evacuation. This is confirmed by research of the National Fire Protection Association (NFPA) conducted in the United States in 2005-2007 [9], according to which audio (not voice) alarm signals were associated, for example, by the respondents with a cell phone ringing. In case of visually impaired and blind people, additional solutions should be applied based on the functions of sound alarming, including navigation with the use of audio messages, as well as messages and markings in the facility with an appropriate colour contrast. The device worn on or the application should cooperate with the infrastructure environment, in which intense colour marking should be provided for such elements as handrails, stairs, floor texturing on communication and escape routes. In case of people with cognitive disabilities, there may be significant disturbances in fully conscious perception of the circumstances of the threatening situation. In particular people in this group should be identified before they enter a facility, as their limitations do not have to be recognizable. There may be problems with the punctuation of text messages. It is reasonable to support them with dedicated audio messages. Also due to unconscious limitations, people in this group may move much slower during evacuation than others. Hence the need for an alternative and safe escape route. For each of the groups mentioned above, the function of identifying and locating a person with cognitive limitations in real time in any part of a facility and adjacent to the facility is particularly important. The above action will shorten the time of arrival of the rescuers or law enforcement services (and ultimately bystanders who are able to provide support during an evacuation) and will create conditions for determining an optimal, alternative evacuation route.

\section{Effective evacuation in intelligent construction}

Unfortunately, it is difficult to find reliable data showing the number of existing and currently emerging intelligent buildings. Based on the observation of microeconomic data, one can try to make an assumption that at least $90 \%$ of the newly constructed buildings in Poland are either fully or largely intelligent buildings [10]. Additionally, as the awareness of the benefits of intelligent construction grows, existing facilities are modernized. What is an intelligent building? It is nothing more than a term for a technologically advanced building equipped with intelligent, automatically controlled technologies. In order to be able to call a building intelligent, it must have a system of sensors and detectors as well as one, integrated management system for all its installations. The field of operation of the integrated Building Management Systems (BMS) is the integration, control, monitoring, optimization and reporting of such elements as, for example, ICT network, lighting, heating, ventilation and air conditioning control, alarm and monitoring systems, fire protection or smoke exhaust control system, control porządkowych, a ostatecznie osób postronnych, będących w stanie udzielić wsparcia (asysta) w czasie ewakuacji. Potwierdzają to badania Narodowego Związku Ochrony Przeciwpożarowej (ang. National Fire Protection Association - NFPA) prowadzone w Stanach Zjednoczonych w latach 2005-2007 [9], wg których sygnały alarmowe dźwiękowe (nie głosowe) były kojarzone przez badane osoby np. z dzwonkiem telefonu komórkowego. W przypadku osób niedowidzących i niewidomych należy zastosować dodatkowe rozwiązania oparte na funkcjach alarmowania dźwiękiem, w tym nawigowania za pomocą komunikatów audio, a także komunikatów oraz oznaczeń w obiekcie o odpowiednim kontraście kolorystycznym. Urządzenie nasobne lub aplikacja powinny współpracować z otoczeniem infrastrukturalnym, w którym należy przewidzieć oznaczenie intensywną barwą, takich elementów jak poręcze, schody, teksturowanie podłóg na ciągach komunikacyjnych i drogach ewakuacyjnych. W przypadku osób z niepełnosprawnością poznawczą mogą wystąpić istotne zakłócenia w pełni świadomym postrzeganiu okoliczności sytuacji zagrażającej. Osoby w tej grupie należy w szczególności identyfikować zanim znajdą się na terenie obiektu, gdyż ich ograniczenia nie muszą być rozpoznawalne. Mogą wystąpić problemy z interpunkcją komunikatów tekstowych. Zasadnym jest wsparcie za pomocą dedykowanych komunikatów audio. Osoby $w$ tej grupie - z powodu również nieuświadomionych ograniczeń - mogą w czasie ewakuacji przemieszczać się znacznie wolniej od pozostałych. Stąd potrzeba umożliwienia alternatywnej i bezpiecznej ścieżki ewakuacji. Dla każdej z wymienionych wyżej grup szczególnie istotną jest funkcja umożliwiająca identyfikację i lokalizowanie osoby z ograniczeniami poznawczymi w czasie rzeczywistym w dowolnej części obiektu oraz na terenie przyległym do obiektu. Powyższe działanie skróci czas dotarcia ratowników lub służb porządkowych (a ostatecznie osób postronnych, będących w stanie udzielić wsparcia w czasie ewakuacji) oraz stworzy warunki do wytyczenia optymalnej, alternatywnej drogi ewakuacji.

\section{Skuteczna ewakuacja w inteligentnym budownictwie}

Niestety trudno znaleźć wiarygodne dane pokazujące liczbę istniejących i powstających aktualnie inteligentnych budynków. Na podstawie obserwacji danych mikroekonomicznych, można spróbować postawić tezę, że co najmniej $90 \%$ nowo powstających budynków w Polsce to albo w pełni, albo w znakomitej większości budynki inteligentne [10]. Dodatkowo, wraz ze wzrostem świadomości dotyczącej korzyści wynikających z inteligentnego budownictwa, istniejące obiekty są modernizowane. Czym jest inteligentny budynek? To nic innego jak określenie wysoko zaawansowanego technicznie i wyposażonego w inteligentne, automatycznie sterowane technologie budynku. Aby móc nazwać budynek inteligentnym, musi on posiadać system czujników i detektorów oraz jeden, zintegrowany system zarządzania wszystkimi znajdującymi się w nim instalacjami. Polem działania zintegrowanego systemu zarządzania budynkiem (ang. Building Management Systems - BMS ) jest integracja, kontrola, monitorowanie, optymalizacja i raportowanie, takich elementów jak np. sieć teleinformatyczna, 
and monitoring of fire dampers. From the above it can be concluded that computer-aided tools that automate decision-making regarding the functioning of an intelligent building are now an integral part of the planning and management process in the event of threats, but so far they have not been used in Poland in the field of automation of the evacuation of people with disabilities. This system could constitute an additional, unique solution, enriching the typical scope of data already existing in BMS systems in intelligent buildings [10].

The use of evacuation support and automation systems would enable unambiguous identification of disabled people in the facilities. Creating compatible organizational solutions - in the form of evacuation scenarios appropriate for the type of disability developed under the Fire Safety Instructions - should, in the first place, increase the effectiveness of evacuation in an emergency. Additionally, collecting and intelligent analysis of information about the location of disabled people in a facility, combined with unambiguous identification of the type of their disability, would also shorten the time of their evacuation. The evacuation support and automation system in the form of an integrated IT solution connected with wearable devices would ensure the location and identification of people with disabilities in almost real time and would enable the transfer of this key information to the rescuers in an emergency. This, in turn, would allow to acquire knowledge about the exact location of the people at risk, as early as the stage of alerting, and even to simultaneously communicate the procedure until the emergency services arrive. Thanks to the use of algorithms using machine learning, the rescuers at an emergency site, even while traveling, could use mobile devices (such as tablets or smartphones) to receive the optimal path mapped out by the system to reach people requiring assistance in evacuation or assistance due to injuries. Taking the shortest possible path is a condition for shortening the evacuation time in general. In an emergency, it is often the time of the rescuer to reach the injured that is a critical condition for determining the final effectiveness of the undertaken rescue actions.

\section{Conclusions}

In public utility facilities, providing such technological solutions and organizational solutions compatible with them, which take into account the specificity of individual types of disabilities of people who have the right to stay in these facilities seems of key importance. This requirement should - following the intended use of the provisions in force in the field of fire protection [11] and regulations concerning the accessibility of public utility facilities [2] - constitute a specific standard and an obligatory requirement of application. This will require prior sterowanie oświetleniem, ogrzewaniem, wentylacją i klimatyzacją, system alarmowy i monitoringu, przeciwpożarowy czy system sterowania oddymianiem pożarowym, sterowanie i monitorowanie klap przeciwpożarowych. Z powyższego wynika, że wspomagane komputerowo narzędzia automatyzujące podejmowanie decyzji dot. funkcjonowania inteligentnego budynku są dziś nieodłączną częścią procesu planowania i zarządzania na wypadek zagrożeń, jednak do tej pory nie były one w Polsce wykorzystywane w zakresie automatyzacji ewakuacji osób niepełnosprawnych. System ten mógłby stanowić dodatkowe, unikalne rozwiązanie, wzbogacające typowy zakres danych, istniejących już w systemach BMS w inteligentnych budynkach [10].

Zastosowanie systemów wsparcia i automatyzacji ewakuacji umożliwiłoby jednoznaczną identyfikację osób niepełnosprawnych w obiektach. Stworzenie kompatybilnych rozwiązań organizacyjnych - w postaci opracowanych w ramach Instrukcji Bezpieczeństwa Pożarowego odpowiednich dla rodzaju niepełnosprawności scenariuszy ewakuacji - powinno, w pierwszej kolejności, podnieść efektywność ewakuacji w sytuacji zagrożenia. Dodatkowo, gromadzenie i inteligentna analiza informacji o lokalizacji osób niepełnosprawnych w obiekcie, w połączeniu z jednoznaczną identyfikacją rodzaju ich niepełnosprawności pozwoliłoby także na skrócenie czasu ich ewakuacji. System wsparcia i automatyzacji ewakuacji w postaci zintegrowanego rozwiązania informatycznego połączonego z urządzeniami nasobnymi zapewniałby lokalizację i identyfikację osób niepełnosprawnych w czasie niemal rzeczywistym oraz umożliwiałoby transfer tych kluczowych w sytuacji zagrożenia informacji do ratowników. To zaś pozwalałoby właściwie już na etapie alarmowania na pozyskanie wiedzy o dokładnym miejscu przebywania zagrożonych osób, a nawet na jednoczesną komunikację ze wskazaniem, dotyczącym postępowania do momentu dotarcia służb ratowniczych. Dzięki zastosowaniu algorytmów wykorzystujących uczenie maszynowe ratownicy dysponowani na miejsce zagrożenia, nawet już w czasie dojazdu, mogliby za pomocą urządzeń mobilnych (typu tablet lub smartfon) otrzymywać wytyczoną przez system optymalną ścieżkę dotarcia do osób wymagających asysty w ewakuacji lub pomocy na skutek odniesionych obrażeń. Obranie możliwie najkrótszej ścieżki dotarcia to warunek skrócenia czasu ewakuacji w ogóle. W sytuacji zagrożenia niejednokrotnie to właśnie czas dotarcia ratownika do osób poszkodowanych stanowi warunek krytyczny do określenia ostatecznej skuteczności podejmowanych działań ratowniczych.

\section{Wnioski}

W obiektach użyteczności publicznej kluczowym wydaje się zapewnienie takich rozwiązań technologicznych oraz kompatybilnych z nimi rozwiązań organizacyjnych, które będą uwzględniały specyfikę poszczególnych rodzajów niepełnosprawności osób mających prawo do przebywania na terenie tych obiektów. Wymóg ten powinien - w ślad za przeznaczeniem dotychczas obowiązujących przepisów w zakresie ochrony przeciwpożarowej [11] oraz regulacji dotyczących dostępności obiektów użyteczności publicznej [2] - stanowić swoisty standard i obligatoryjny wymóg 
determination of such a standard - as a point of reference for designers of facilities, security systems, facility managers and rescue services. The current availability of technology means that the optimization of rescue operations (thanks to the identification of disabled people in a facility as soon as they appear on the premises as users of this space, their precise location, and the possibility of sharing data on the number of people potentially requiring support during evacuation from a facility in an emergency) remains within the reach of modern designers and facility managers. Using intelligent technologies to support the evacuation seems - as never before - not only possible to be applied in practice, but even necessary, taking into account both the growth of the newly emerging, intelligent utility infrastructure, the participation of people with special needs in the general public, and the emergence of more and more numerous types of threats occurring in facilities, both those caused by natural forces as a result of rapid climate changes, and, unfortunately, due to bad will of people, posing a threat to society. Despite the variety of causes of threats that can occur in public facilities, the effective evacuation of people with motor or perception dysfunctions, regardless of the type of threat, will pose the same challenge. It will mainly come down to when the rescuers will have access to information on the number of people requiring support during the evacuation, the degree and type of dysfunctions they have, and their precise location. Another key element seems to be taking into account (at the design stage and later when equipping facilities with installations) systems and organizational solutions, assuming the possibility of evacuation of people with various types of dysfunctions and therefore taking into account (in evacuation plans and fire safety instructions adequate to the specificity of the dysfunction) evacuation scenarios which can be supported by available, intelligent and commonly used technologies. This approach seems even more justified when one takes into account the multitude of variables that should be taken into account when designing solutions dedicated to people with disabilities. One of them is - often difficult to be understood by people without disabilities who are responsible for developing evacuation scenarios and compatible instructions - the effort that a disabled person must put into evacuation. Often times, it is an effort that is disproportionate to the physical loads that are commonly known to us, which a person is subjected to in the phase of alerting about a threat. In Anglo-Saxon countries, in line with this awareness, efforts are made not to involve people with disabilities in carrying out evacuation trials. At the same time, attempts are made to simulate probable scenarios involving people with various types of dysfunctions as faithfully as possible, using currently available technologies. On this basis, optimal evacuation paths are determined, clear and legible procedures are selected, personnel responsible for assisting the evacuation of disabled people are trained, and the facility is equipped with supporting devices in accordance with the conclusions of an unlimited number of simulations. Numerical modelling is an available method that enables the simulation and assessment of evacuation times. It seems to be much more credible than the exercises carried out with the participation of disabled people. It enables the comparison of two key variables, i.e. the available safe evacuation time with the stosowania. Wymagać to będzie uprzedniego określenia takowego standardu - jako punktu odniesienia dla projektantów obiektów, systemów zabezpieczeń oraz zarządców obiektów i służb ratowniczych. Obecna dostępność technologii sprawia, że optymalizacja działań ratowniczych (dzięki identyfikacji w obiekcie osób niepełnosprawnych już w momencie, w którym pojawiają się one na terenie obiektu jako użytkownicy tej przestrzeni, ich precyzyjnej lokalizacji, a także dzięki możliwości udostępniania danych dotyczących liczby osób potencjalnie wymagających wsparcia w ewakuacji z obiektu w sytuacji zagrożenia) pozostaje jak najbardziej w zasięgu współczesnych projektantów i zarządców obiektów. Wykorzystanie do wsparcia ewakuacji inteligentnych technologii wydaje się - jak nigdy wcześniej - nie tylko możliwym do zastosowania w praktyce, ale wręcz koniecznym, biorąc pod uwagę zarówno przyrost nowo powstającej, inteligentnej infrastruktury użytkowej, udział w ogóle społeczeństwa osób o szczególnych potrzebach, jak i pojawianie się coraz liczniejszych i częściej występujących na obiektach rodzajów zagrożeń zarówno tych powodowanych siłami natury na skutek gwałtownych zmian klimatu, jak i niestety z powodów złej woli ludzi, stanowiących zagrożenie dla społeczeństwa. Mimo różnorodności przyczyn zagrożeń, możliwych do wystąpienia w obiektach użyteczności publicznej, skuteczna ewakuacja osób posiadających dysfunkcje ruchowe lub percepcji, bez względu na rodzaj zagrożenia, będzie stanowiła takie samo wyzwanie. W głównej mierze będzie ono sprowadzało się do tego, kiedy ratownicy będą mieć dostęp do informacji o liczbie osób wymagających wsparcia w ewakuacji, stopniu i rodzaju posiadanych przezeń dysfunkcji oraz ich precyzyjnej lokalizacji. Kolejnym, kluczowym elementem wydaje się uwzględnienie na etapie projektowania i późniejszego wyposażania obiektów w instalacje, systemów oraz rozwiązań organizacyjnych, zakładających ewentualność ewakuacji osób posiadających poszczególne rodzaje dysfunkcji i w związku z tym uwzględniających (w planach ewakuacji oraz instrukcjach bezpieczeństwa pożarowego adekwatnych do specyfiki dysfunkcji) scenariuszy ewakuacji, które mogą być wspierane z poziomu dostępnych, inteligentnych i powszechnie wykorzystywanych technologii. Takie podejście wydaje się tym bardziej zasadne, gdy uwzględni się wielość zmiennych, które należy brać po uwagę projektując rozwiązania dedykowane osobom niepełnosprawnym. Jedną z nich jest nierzadko trudny do uświadomienia przez osoby pełnosprawne, które odpowiadają za opracowanie scenariuszy ewakuacji oraz kompatybilnych instrukcji - wysiłek, jaki osoba niepełnosprawna musi włożyć w ewakuację. Częstokroć jest to wysiłek niewspółmierny do powszechnie znanych nam obciążeń fizycznych, jakim człowiek jest poddawany $w$ fazie alarmowania o zagrożeniu. W państwach anglosaskich, zgodnie z tą świadomością, podejmuje się staranie, aby nie angażować osób niepełnosprawnych do realizacji próbnych ewakuacji. Jednocześnie próbuje się, aby możliwie jak najwierniej przy wykorzystaniu dostępnych obecnie technologii symulować prawdopodobne scenariusze z udziałem osób posiadających różnego rodzaju dysfunkcje. Na tej głównie podstawie określa się optymalne ścieżki ewakuacji, dobiera zrozumiałe i czytelne procedury, szkoli się personel odpowiedzialny za asystę podczas ewakuacji osób niepełnosprawnych oraz wyposaża obiekt w urządzenia wspomagające zgodnie z wnioskami 
required safe evacuation time. It offers an infinite number of repetitions to optimize the entire process. Assumptions regarding evacuation plans preceded by a simulation based on numerical modelling should be considered as a more precise method than the inference currently in force in Poland based only on statistical data or on declared values such as the area or number of people, beds in a facility. The presented approach has one more advantage, because it allows for the continuous improvement of the adopted procedures and solutions without the need to strain people with dysfunctions. It also does not disturb the day-to-day operation of a given facility and thus does not generate losses and costs. Considering the above, it seems reasonable to conclude that also in Poland, it is useful (from a practical point of view, but also in the light of the Supreme Audit Office's post-inspection recommendations) to develop a specific guide that constitutes a standard in the design and improvement of solutions aimed at supporting the evacuation of people with disabilities from public facilities. In addition, it would be advisable for each fire safety instruction to include a mandatory part of the organizational and technological solutions dedicated to disabled people adopted in a facility, which in its final form should result from the analyses based on the guide mentioned above. z nieograniczonej liczby symulacji. Modelowanie numeryczne to dostępna metoda pozwalająca na symulację i ocenę czasów ewakuacji. Wydaje się ona o wiele bardziej wiarygodna niż realizowane ćwiczenia z udziałem osób niepełnosprawnych. Umożliwia ona porównanie dwóch kluczowych zmiennych, tj. dostępnego czasu bezpiecznej ewakuacji z wymaganym czasem bezpiecznej ewakuacji. Oferuje przy tym nieskończoną liczbę powtórzeń, celem optymalizacji całego procesu. Założenia co do planów ewakuacji poprzedzone symulacją w oparciu o modelowanie numeryczne powinno być rozważane jako metoda bardziej precyzyjna niż obowiązujące obecnie w Polsce wnioskowanie na podstawie jedynie danych statystycznych czy też deklarowanych wartości, takich jak powierzchnia czy liczba osób, łóżek występujących w obiekcie. Prezentowane podejście ma jeszcze jedną zaletę, otóż pozwala na ciągłe doskonalenie przyjętych procedur i rozwiązań bez konieczności nadwyrężania osób posiadających dysfunkcje. Nie powoduje ono także zakłóceń w bieżącym funkcjonowaniu danego obiektu i tym samym nie generuje strat i kosztów. Biorąc powyższe pod uwagę, zasadnym wydaje się wniosek, że również w Polsce przydatnym (z praktycznego punktu widzenia, ale również w świetle zaleceń pokontrolnych NIK) jest opracowanie swoistego przewodnika stanowiącego standard w zakresie projektowania i doskonalenia rozwiązań mających na celu wsparcie ewakuacji osób niepełnosprawnych z obiektów użyteczności publicznej. Ponadto, wskazane byłoby, aby w każdej instrukcji bezpieczeństwa pożarowego znalazła się obowiązkowa część przyjętych w obiekcie rozwiązań organizacyjnych i technologicznych dedykowanych osobom niepełnosprawnym, która w swoim ostatecznym kształcie powinna wynikać $z$ analiz opartych na wspomnianym wyżej przewodniku.

\section{Literature / Literatura}

[1] Przygotowanie jednostek publicznych województwa wielkopolskiego do ewakuacji osób niepełnosprawnych, Delegatura NIK w Poznaniu, https://www.nik.gov.pl/kontrole/I/18/001/LPO/ [dostęp: 29.06.2021].

[2] Ustawa z dnia 19 lipca 2019 r. o zapewnianiu dostępności osobom ze szczególnymi potrzebami (Dz. U. 2019 poz. 1696).

[3] https://www.funduszeeuropejskie.gov.pl/strony/o-funduszach/fundusze-europejskie-bez-barier/dostepnosc-plus/o-programie/ [dostęp: 29.06.2021].

[4] Emergency Evacuation Planning Guide for People with Disabilities, National Fire Protection Association, https://www. nfpa.org/-/media/Files/Public-Education/By--topic/Disabilities/EvacuationGuidePDF.ashx?la=en [dostęp: 29.06.2021].

[5] Rozporządzenie Ministra Infrastruktury z dnia 12 kwietnia 2002 r. w sprawie warunków technicznych, jakim powinny odpowiadać budynki i ich usytuowanie (Dz. U. z 2015 r. poz. 1422).

[6] Rozporządzenie Ministra Spraw Wewnętrznych i Administracji z dnia 2 grudnia 2015 r. w sprawie uzgadniania projektu budowlanego pod względem ochrony przeciwpożarowej (Dz. U. z 2015 r. poz. 2117).

[7] Rozporządzenie Ministra Spraw Wewnętrznych i Administracji z dnia 7 czerwca 2010 r. w sprawie ochrony przeciwpożarowej budynków, innych obiektów budowlanych i terenów (Dz. U. z 2010 r. Nr 109, poz. 719).

[8] Miśkiewicz P., Światowy Raport o Niepełnosprawności, Biuro WHO w Polsce, https://www.pfron.org.pl/fileadmin/files/p/4955_Paulina_Mi_kiewicz.pdf [dostęp: 29.06.2021].

[9] O'Neil Ch., Time to Evacuate: Fire Alarms Systems Are Failing to Address Their Intended Purpose, http://ceas.uc.edu/content/dam/aero/docs/fire/Papers/Evacuate.pdf [dostęp: 29.06.2021]

[10] https://www.prnews.pl/popularne-sa-inteligentne-domy-polsce-raport-442374 [dostęp: 29.06.2021]. 
[11] Ustawa z dnia 24 sierpnia 1991 r. o ochronie przeciwpożarowej (Dz. U. z 2019 r. poz. 1372; zm. Dz. U. z 2019 r. poz. 1518.).

[12] Ustawa z dnia 22 grudnia 2015 r. o Zintegrowanym Systemie Kwalifikacji (Dz.U. z 2018 poz. 2153 z późn. zm.)

[13] Ustawa z dnia 16 kwietnia 2004 r. o wyrobach budowlanych (Dz. U. nr 92 poz. 881 z późn. zm.).

[14] Rozporządzenie Ministra Infrastruktury i Budownictwa z dnia 17 listopada 2016 r. w sprawie sposobu deklarowania właściwości użytkowych wyrobów budowlanych oraz sposobu znakowania ich znakiem budowlanym (Dz. U. z 2016 r. poz. 1966 z późn. zm.).

[15] Promoting Safe Egress and Evacuation for People with Disabilities, National Disability Authority, https://www. ac-cessibletourism.org/resources/accessible-egress-report.pdf [dostęp: 29.06.2021].

[16] Tuśnio N., Wolny P., Ewakuacja osób z niepełnosprawnościami, „Przegląd Pożarniczy” 2020, 1, 10-13.

[17] Tuśnio N., Wolny P., Ewakuacja - propozycja zmian, „Przegląd Pożarniczy" 2020, 6, 21-23.
PAWEL FLOREK, BE - a graduate of the Faculty of Law at the SWPS University of Social Sciences and Humanities in Warsaw, where he graduated from the Faculty of Internal Security. Specialist in the Support and Audit Department at Centrum Naukowo-Badawcze Ochrony Przeciwpożarowej - Państwowy Instytut Badawczy in Józefów. Fire protection inspector, member of a team of authors of 7 new qualifications in the field of design, installation and maintenance of fire protection at CNBOP-PIB included in ZSK, as well as the originator of the qualification for the installation and maintenance of alarm detectors.

BRIG. TOMASZ KOŁODZIEJCZYK, M.SC. ENG. - employee of Project and Research Service Department at CNBOP-PIB. A graduate of full-time uniform studies at the Main School of Fire Service, as well as post-graduate studies in Fire Engineering of Buildings at the Faculty of Civil and Environmental Engineering at the Poznań University of Technology and the Faculty of Fire Safety Engineering at SGSP. A co-author of a study entitled Selected functional and safety issues in photovoltaic installations. He has many years of experience in the field of civil protection and humanitarian aid in the national and international dimension.
LIC. PAWEL FLOREK - absolwent Wydziału Prawa SWPS Uniwersytetu Humanistycznospołecznego w Warszawie, gdzie ukończył studia na kierunku Bezpieczeństwo Wewnętrzne. Specjalista w Dziale Wsparcia i Audytów w Centrum Naukowo-Badawczym Ochrony Przeciwpożarowej - Państwowym Instytucie Badawczym w Józefowie. Inspektor ochrony przeciwpożarowej, członek zespołu autorów 7 nowych kwalifikacji z zakresu projektowania, montażu i konserwacji zabezpieczeń przeciwpożarowych w CNBOP-PIB włączonych do ZSK, a także pomysłodawca kwalifikacji dotyczącej montażu i konserwacji autonomicznych czujek.

BRYG. MGR INŻ. TOMASZ KOŁODZIEJCZYK - pracownik Działu Projektów i Obsługi Badań w CNBOP-PIB. Absolwent studiów dziennych mundurowych Szkoły Głównej Służby Pożarniczej, a także studiów podyplomowych z zakresu Inżynierii Pożarowej Budynków Wydziału Budownictwa i Inżynierii Środowiska Politechniki Poznańskiej i Wydziału Inżynierii Bezpieczeństwa Pożarowego SGSP. Współautor opracowania pt. Wybrane zagadnienia użytkowe i bezpieczeństwa winstalacjach fotowoltaicznych. Posiada wieloletnie doświadczenie w zakresie problematyki ochrony ludności i pomocy humanitarnej w wymiarze krajowym oraz międzynarodowym. 